\title{
Assessment literacy of foundation phase teachers: An exploratory study
}

\author{
Anil Kanjee, Tshwane University of Technology.* \\ Jane Mthembu, Tshwane University of Technology.
}

\begin{abstract}
This study explores foundation phase teachers' assessment literacy, and their understanding and use of formative and summative assessment. Using questionnaires, observations and interviews, data were obtained from Grade 1, 2 and 3 teachers from a school each in quintile 2, 3 and 5. Teachers from all three schools demonstrated equally low levels of assessment literacy. While understanding of summative assessment was noticeably higher, all teachers demonstrated very poor understanding of formative assessment. Notwithstanding the small sample size, the study highlights the need for professional development programmes to focus on enhancing teachers' assessment literacy. It also calls for additional research on a conceptualisation of assessment literacy that is relevant to South African teachers, and for determining the impact of concepts and practices advocated in the national assessment and curriculum policies on teachers' use of assessment to address the learning needs of all learners across schools in the different quintile categories.
\end{abstract}

Keywords: assessment literacy, foundation phase, formative assessment, summative assessment, assessment policy, quintile category

*Email address: KanjeeA@tut.ac.za.

South African Journal of Childhood Education | 2015 5(1): 142-168 | ISSN: 2223-7674 |๔ UJ

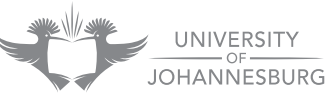




\section{Introduction}

Assessment comprises an integral part of teachers' classroom practices, and its effective use has the potential to significantly improve learning and learner performance (Black \& Wiliam 1998). However, if they are to successfully address the diverse learning needs of all children, teachers must be sufficiently knowledgeable and competent to use assessment for both summative and formative purposes. The effective use of assessment for identifying and addressing specific learner needs is especially relevant during the foundation phase of schooling as children begin to further develop and enhance their cognitive and affective capacities for learning new knowledge and skills, thereby establishing a foundation for future development.

Since the advent of the new education dispensation in 1994 (Kanjee \& Sayed 2013; RSA DBE 2009; RSA DoE 2000), the issue of assessment has been an area of neglect and debate in the South African schooling system (Pahad 1999). Most teachers have limited knowledge and expertise in this area, and lack appropriate guidance and support on how to effectively use assessment for addressing the learning needs of all children (Kanjee \& Croft 2012; Pryor \& Lubisi 2002; RSA DoE 2000; RSA DBE 2009; Vandeyar \& Killen 2007). While a number of studies have been conducted on teacher assessment practices (Kanjee 2009; Kuze \& Shumba 2011; Pryor \& Lubisi 2002; Vandeyar \& Killen 2007), there has been limited research on teachers' assessment literacy, particularly in the foundation phase. In their review of assessment and learning in developing nations, Sayed, Kanjee and Rao (2014) note that there are large gaps in our knowledge of assessment practices during the early years, and argue that more research is required about how often teachers should assess and monitor children's learning, the types of formal and informal assessments of learning that are being used by teachers, the reliability and validity of the assessment instruments used, and the impact of the different forms of assessment on early learning.

The purpose of this paper is to explore foundation phase teachers' assessment literacy and how it impacts on their daily practice. Assessment literacy is defined as "an individual's understandings of the fundamental assessment concepts and procedures deemed likely to influence educational decisions" (Popham 2009:267). Specifically, the study explores notions and concepts of assessment literacy that are applicable to the South African context and reviews teachers' understanding of summative and formative assessment, their views and use of assessment policy, and how they implement assessment in their classrooms. This is an exploratory study conducted in three schools, and does not claim to provide findings that are representative of all foundation phase teachers in South Africa. Rather, the study aims to contribute to the ongoing debate about teachers' understanding and use of assessment, and the implications of this for current policy and practice at the foundation phase level. The paper begins with a brief overview of assessment in the foundation phase. This is followed by a review of the concept of assessment literacy and its conceptualisation for the South African context. Next, the methodology and design of the study are presented, followed by the findings and a discussion of the results. The paper concludes by highlighting the importance of the findings, describing the limitations of the study, and noting the implications for practice and further research. 


\section{Assessment in the foundation phase}

The early years of school are a sensitive period in the development of lifelong learning and the acquisition of skills, knowledge, behaviours, values and attitudes that support learning in the later years (DeLuca, Chavez, Bellara \& Cao 2013). When young children come to school, they bring with them their natural curiosity about their world, as well as different interests, strengths, abilities and cultural backgrounds. Hendy and Whitebread (2000) note that it is the role of the foundation phase teacher to plan and provide learning experiences that will usefully incorporate each child's unique development and foster independent learning. Similarly, Hill, Smith, Cowie et al (2013) argue that children need to be supported in taking control of their own learning.

Children in the early years comprehend through doing as well as listening, and often express themselves through physical behaviour and play (Shepard, Kagan \& Wurtz 1998); hence, they need naturalistic opportunities to demonstrate their skills (Niemeyer \& Scott-Little 2001). This requires teachers to ensure that assessment information is obtained from authentic settings and situations that reflect children's actual performance. Rao and Sun (2010) note that when considering issues of assessment, it is important to evaluate the quality of the learning environments that young children have been placed in. Thus, teachers must acquire the requisite understanding and knowledge to use assessment evidence and be able to account for the context within which learining takes place to effectively address the learning needs of children.

In his study on teacher conceptions of assessment, Brown (2004) reports that all pedagogical acts are affected by the understanding teachers have about teaching, learning, assessment and the curriculum. In two studies with schoolteachers in South Africa, Sethusha (2012) showed that teachers construct their own understanding of assessment, based on their classroom experience; while Van Laren and James (2008) found that teachers' understanding of assessment and the assessment policy had an impact of how they assessed in the classroom. As Richardson (2003) argues, there is a continuous interaction between knowledge, belief and practice in teacher professional development. Our view is that this interaction is also true of teachers' assessment practices. We propose that successful teacher development programmes should target changes to teachers' knowledge and their understanding of, and beliefs about, the phenomenon of assessment. Once teachers have changed their understanding of assessment, it may well follow that their teaching practice will also change. Henning (2013) reported a pilot study where teachers' thinking about children's learning changed the teachers' discourse; moreover, the study indicated that, as a result of this shift, their practice was also changing.

Teachers' understanding of assessment is also linked to their stance toward the curriculum. In the foundation phase, there is a traditional developmental programme and academically oriented curriculum (Pyle \& DeLuca 2013). A developmentally appropriate programme focuses on the child's social, emotional and cognitive development, while the academically motivated programme focuses on the development of academic skills 
(Pyle \& DeLuca 2013). Teachers' assessment practices are influenced by these different curricular orientations, and research indicates that teachers generally struggle to balance the two (Hariparsad 2004; Pyle \& DeLuca 2013; Sokopo 2004).

\section{Assessment literacy: Definitions and conceptualisations}

A review of the literature reveals limited consensus on the definition and set of knowledge and skills that constitute assessment literacy (Brookhart 2011; Popham 2009; Quilter \& Gallini 2000; Stiggins 1999). In an attempt to obtain consensus on the key assessment knowledge and skills that teachers should have and guide teacher education programmes in the United States, the American Federation of Teachers (AFT), the National Council on Measurement in Education (NCME) and the National Education Association (NEA) jointly defined seven Standards for Teacher Competence in Educational Assessment of Students (AFT, NCME \& NEA 1990). These standards stipulated that teachers should be skilled in choosing and developing assessment methods appropriate for instructional decisions; administering, scoring and interpreting results of externally produced and teacher-made assessments; using assessment results when making educational decisions; developing valid grading procedures; communicating assessment results to various audiences; and recognizing unethical, illegal, and inappropriate methods and uses of assessment.

Stiggins (1999) argued for a revision of these standards and, in turn, proposed seven competencies that teachers should posses in order to be considered assessment literate: (i) connecting assessments to clear purposes; (ii) clarifying achievement expectations; (iii) applying proper assessment methods; (iv) developing quality assessment exercises and scoring criteria, and sampling appropriately; ( $v$ ) avoiding bias in assessment; (vi) communicating effectively about student achievement; and (vii) using assessment as an instructional intervention.

Similarly, in her review of the Standards (AFT, NCME \& NEA 1990) twenty years later, Brookhart (2011) argued that the 1990 Standards do not adequately address the current education context of teachers with regard to recent conceptions of formative assessment knowledge and skills and the effects of accountability and standards-based reform on teachers' classroom practices. In order to address these limitations, Brookhart (ibid) proposed an extended set of assessment knowledge and skills that teachers require (see Table 1 ). In their conceptualisation, Gotch and French (2014) note that assessment literacy includes using multiple high-quality assessments that are aligned with precisely defined achievement targets; interpreting student performance in the light of the particular form of assessment and potential impact of extraneous factors; administering and scoring assessments appropriately; accurately communicating results to interested parties; and carrying out all assessment responsibilities legally and ethically. 


\section{Table 1: Teacher assessment knowledge and skills proposed by Brookhart (2011)}

\begin{tabular}{|c|c|}
\hline 1. & should understand learning in the content area that they teach. \\
\hline 2. & $\begin{array}{l}\text { Teachers should be able to articulate clear learning intentions that are congruent with } \\
\text { both the content and depth of thinking implied by standards and curriculum goals, and } \\
\text { do this in such a way that they are attainable and assessable. }\end{array}$ \\
\hline 3. & $\begin{array}{l}\text { Teachers should have a repertoire of strategies for communicating to students what } \\
\text { achievement of a learning intention looks like. }\end{array}$ \\
\hline 4. & $\begin{array}{l}\text { Teachers should understand the purposes and uses of the range of available assessment } \\
\text { options and be skilled at using them. }\end{array}$ \\
\hline 5. & $\begin{array}{l}\text { Teachers should have the skills to analyse classroom questions, test items and } \\
\text { performance assessment tasks, in order to ascertain the specific knowledge and } \\
\text { thinking skills required for students to do them. }\end{array}$ \\
\hline 6. & Teachers should have the skills to provide effective, useful feedback on student work. \\
\hline 7. & $\begin{array}{l}\text { Teachers should be able to construct scoring schemes that quantify student } \\
\text { performance on classroom assessments into useful information for decisions about } \\
\text { students, classrooms, schools and districts. These decisions should lead to improved } \\
\text { student learning, growth or development. }\end{array}$ \\
\hline 8. & $\begin{array}{l}\text { Teachers should be able to administer external assessments and interpret their results } \\
\text { for decisions about students, classrooms, schools and districts. }\end{array}$ \\
\hline 9. & $\begin{array}{l}\text { Teachers should be able to articulate their interpretations of assessment results and } \\
\text { their reasoning about the educational decisions based on assessment results to the } \\
\text { educational populations they serve (students and their families, class, school and } \\
\text { community). }\end{array}$ \\
\hline 10. & $\begin{array}{l}\text { Teachers should be able to help students to use assessment information to make sound } \\
\text { educational decisions. }\end{array}$ \\
\hline 11. & $\begin{array}{l}\text { Teachers should understand and carry out their legal and ethical responsibilities } \\
\text { regarding assessment as they conduct their work. }\end{array}$ \\
\hline
\end{tabular}

According to Quilter and Gallini (2000:116), assessment literacy can be defined as "the ability to design, select, interpret, and use assessment results appropriately for educational decisions". This definition is based primarily on notions of testing and measurement. As Quilter and Gallini note, "few teachers are well prepared to deal with the realities of interpreting, evaluating, and using test results for a variety of purposes" (ibid:117). For Popham (2009), basic understanding constitutes a critical aspect of teacher assessment literacy, as opposed to teachers' technical ability to master different measurement procedures. Thus, Popham (ibid:268) notes that

[...] teachers must comprehend the essence of what actually constitutes a test's reliability and, in general terms, how it is that different reliability coefficients can represent a test's measurement consistency in several distinctive ways.

From this perspective, teachers must not only understand key concepts like validity, but also how these concepts influence the educational decisions they make on a daily 
basis. For Popham, assessment literacy “consists of an individual's understanding of the fundamental assessment concepts and procedures deemed likely to influence educational decisions" (2009:267). While Popham proposes a number of key content areas regarding a set of target skills and knowledge, these focus primarily on decisions related to testing and accountability measures, with limited focus on formative assessments.

\section{Assessment literacy: Relevance to South African teachers}

As part of the process of identifying fundamental concepts and procedures, we reviewed the relevant assessment and curriculum policies promulgated in South Africa since 1994. The primary aim of the first assessment policy introduced by the postapartheid Department of Education (DoE) was to

[...] introduce a shift from a system that is dominated by public examinations, which are 'high stakes' and whose main function has always been to rank, grade, select and certificate learners, to a new system that informs and improves the curriculum and assessment practices of educators and the leadership, governance and organisation of learning sites.

(RSA DoE 1998:4)

Continuous assessment (CASS) was proposed as the preferred method for implementing the policy and is described as

[...] the best model to assess outcomes of learning throughout the system and enable improvements to be made in the learning and teaching process. It must be used to support the learners developmentally and to feed back into teaching and learning, and should not be interpreted merely as the accumulation of a series of traditional test results.

(RSA DoE 1998:5)

The assessment policy defines classroom assessment (CASS) as comprising the use of both formative and summative assessment, and notes that formative assessment is "used to support the learner developmentally and to feed back into the teaching/ learning process", while summative assessment is "used to provide information about a learner's level of competence at the completion of a grade, level or programme" (RSA DoE 1998:16).

Kanjee and Sayed (2013) note that the conceptualization of the 1998 policy was based on Nitko's (1995) notion of CASS, which he presents as comprising two uses or meanings: a summative mark for examinations and test purposes, and a formative evaluation of learner performance. Regarding its practical implications, Nitko cautions that these "different meaning(s) can be confusing and may make the implementation of CASS problematic" (ibid:322). While CASS is proposed as the preferred model for implementation, the policy provides no additional information or any specific guidelines on how CASS should be implemented. In her review of the 1998 assessment policy, Pahad notes that CASS is presented as if "this were the panacea of all inadequacies of past assessment practices and as if the term were self-explanatory" (1999:249). She further argues that the term 'CASS' is interpreted very differently 
by different people, or even by the same people in different contexts, and contends that the policy does not account for the popular interpretation among teachers that CASS means setting more tests and exams on a more regular basis (ibid). However, what the seminal assessment policy did achieve was to foreground the use of both formative and summative assessment, and to emphasise their classroom application for improving learning and teaching.

Two new concepts, 'informal' and 'formal' assessment are introduced in the revised assessment policy introduced in 2007 (RSA DoE 2007). Formal assessments are defined as assessments that provide teachers with a systematic way of evaluating how well learners are progressing in a grade, and should be recorded. Examples of formal assessment provided include projects, oral presentations, demonstrations, tests and exams (ibid). Informal assessment is equated to daily assessments for "the monitoring of learners' progress [...] conducted through observations, discussions, learnerteacher conferences and informal discussions" (ibid:7). The policy notes that these assessments are used for providing feedback to learners and to improve teaching, and need not be recorded. In advocating for assessment to be an integral part of the learning and teaching process, and the use of multiple assessment strategies, the policy specifies that "not everything that is taught should be assessed formally and not everything that is assessed need be recorded" (ibid:11). The 2007 policy also prescribed codes and descriptors for recording and reporting results for the foundation phase (where 1 = 'Not Achieved'; 2 = 'Partial Achievement'; 3 = 'Satisfactory Achievement'; and 4 = 'Outstanding/Excellent Achievement'), as well as the number of formal assessments that teachers must complete for each grade and the different subjects areas within each grade (see Table 2).

Table 2: Number of formal assessment tasks for Grades $\mathrm{R}$ to 3 as prescribed in the 2007 assessment policy (RSA DoE 2007)

\begin{tabular}{|l|c|c|c|c|c|}
\hline \multicolumn{1}{|c|}{ Learning programme } & Term 1 & Term 2 & Term 3 & Term 4 & Total \\
\hline Literacy (Languages) & 4 & 4 & 4 & 4 & 16 \\
\hline $\begin{array}{l}\text { Additional Language } \\
\text { (optional in Grade 1 \&2) }\end{array}$ & 2 & 2 & 2 & 2 & 8 \\
\hline Numeracy (Mathematics) & 3 & 3 & 3 & 3 & 9 \\
\hline Life Skills (Life Orientation) & 1 & 1 & 1 & 1 & 4 \\
\hline
\end{tabular}

In the most recent curriculum and assessment policy statements (CAPS) (RSA DBE 2011b; 2011a; 2011c; 2011d; 2011e), the concepts of 'informal and 'formal' assessment, first introduced in the 2007 policy, are further extended, with specific emphasis on the use of feedback to improve learning and clear links to assessment for learning and assessment of learning, respectively. Specifically, the National protocol for assessment: Grades R-12 (RSA DBE 2011a:4) notes that

Classroom assessment should be both informal and formal. In both cases it is important that learners know what knowledge and skills are being assessed and feedback should be provided to learners after assessment to enhance the learning experience. 
Regarding formal assessment, the protocol notes that

Formal assessment (assessment of learning) provides teachers with a systematic way of evaluating how well learners are progressing in a particular subject and in a grade. Teachers must ensure that assessment criteria are very clear to the learners before the assessment process. This involves explaining to the learners which knowledge and skills are being assessed and the required length of responses.

(RSA DBE 2011a:5)

For each of the subject areas (languages, life skills and mathematics), additional requirements regarding the programme for formal assessment are also specified. For example, Tables 3 and 4 list the specifications for first additional language (RSA DBE 2011b and home language (RSA DBE 2011C), and Table 5 for mathematics (RSA DBE 2011e). No formal assessment requirements are specified for life skills (RSA DBE 2011d); the policy merely notes that

Assessment in Life Skills during the foundation phase is largely informal, and is ongoing. The formal assessment of each learner once per term should be formally recorded by the teacher.

Table 3: Programme of formal assessment: Grade 1 to 3 Home Language

\begin{tabular}{|c|c|c|c|c|c|}
\hline Grade & Term 1 & Term 2 & Term 3 & Term 4 & Total \\
\hline Grade 1 & 1 & 2 & 2 & 2 & 7 \\
\hline Grade 2 & 1 & 2 & 2 & 2 & 7 \\
\hline Grade 3 & 1 & 3 & 3 & 2 & 9 \\
\hline
\end{tabular}

Table 4: Programme of formal assessment: Grade 1 to 3 First Additional Language

\begin{tabular}{|c|c|c|c|c|c|}
\hline Grade & Term 1 & Term 2 & Term 3 & Term 4 & Total \\
\hline Grade 1 & 1 & 2 & 2 & 2 & 7 \\
\hline Grade 2 & 1 & 2 & 2 & 2 & 7 \\
\hline Grade 3 & 1 & 3 & 3 & 2 & 9 \\
\hline
\end{tabular}

Table 5: Programme of formal assessment: Grade 1 to 3 Mathematics

\begin{tabular}{|c|c|c|c|c|c|}
\hline Grade & Term 1 & Term 2 & Term 3 & Term 4 & Total \\
\hline Grade 1 & 2 & 2 & 2 & 1 & 7 \\
\hline Grade 2 & 2 & 2 & 2 & 2 & 8 \\
\hline Grade 3 & 2 & 3 & 3 & 2 & 10 \\
\hline
\end{tabular}

With regard to informal assessment, the protocol specifies that

Informal (assessment for learning) or daily assessment is the monitoring and enhancing of learners' progress. This is done through teacher observation and teacher-learner interactions, which may be initiated by either teachers or learners. Informal or daily assessment may be as simple as stopping during 
the lesson to observe learners or to discuss with the learners how learning is progressing. It should be used to provide feedback to the learners and teachers, close the gaps in learners' knowledge and skills and improve teaching. Informal assessment builds towards formal assessment and teachers should not only focus on the formal assessment.

(RSA DBE 2011a:5)

The various CAPS documents also note that assessment in Grade $\mathrm{R}$ is informal, and that teacher observations should comprise the main technique of assessment (RSA DBE 2011a; 2011b; 2011C). Thus, no formal tasks are stipulated for Grade R learners:

\begin{abstract}
Assessment practices in Grade $R$ should be informal and children should not be subjected to a 'test' situation. For this reason, Assessment Activities have not been included in the Grade R Curriculum and Assessment Policy Document (CAPS). [... ] In Grade R most of the assessment takes place through observation, with the teacher recording the results of the assessment using a checklist. Thus, as the year progresses a full picture of each child complete with challenges and strengths is gradually built. This allows for challenges to be addressed and strengths to be maximised.
\end{abstract}

(RSA DBE 2011C:21)

Concerning the recording and reporting of results, the National protocol for assessment (RSA DBE 2011a) extends the four-point code and descriptors proposed in the 2007 policy (RSA DoE 2007) to seven points and descriptors, and also specifies that no examinations must take place in the foundation phase. For the other grades, however, all formal assessment tasks have to be marked and formally recorded by the teacher and used for progression and certification purposes.

\title{
Defining assessment literacy
}

Given the different definitions of assessment literacy and the limited consensus regarding the knowledge and skills required by teachers, as well as uncertainty about the validity of American-based definitions and understandings for the South African context, we sought to develop a concept of assessment literacy that would be relevant to South African teachers. We based our work on the definition by Popham (2009) and the teacher assessment knowledge and skills proposed by Brookhart (2011) discussed earlier. We thus derived the fundamental assessment concepts and procedures deemed likely to influence educational decisions of South African teachers from the requirements specified in the curriculum and assessment policy documents (RSA DBE 2011a; 2011b; 2011c, 2011d; 2011e), identified separately for summative and formative assessment. These include knowledge and understanding regarding the articulation of learning intentions from curriculum objectives and definitions of key concepts, as well as purpose and practical applications in the classroom (See Table 6). 
Table 6: Assessment literacy knowledge and skills requirements for South African teachers

\begin{tabular}{|c|c|}
\hline & \\
\hline $\begin{array}{l}\text { - } \text { Clarifying curriculum objectives } \\
\text { - } \text { Definition of classroom assessment } \\
\text { - } \text { Mefinition of continuous assessment } \\
\text { - } \quad \text { Definition and use of summative } \\
\text { - } \text { assessment } \\
\text { - } \text { Sefinition of formal assessment } \\
\text { - Types of questions used for formal } \\
\text { - } \text { assessment } \\
\text { - Meaning of reliability and validity } \\
\text { - Use of results to improve learning and } \\
\text { teaching }\end{array}$ & $\begin{array}{l}\text { - } \text { Clarifying curriculum objectives } \\
\text { - } \text { Definition of classroom assessment } \\
\text { - } \quad \text { Steps for introducing lessons } \\
\text { - } \quad \text { Definition and use of formative } \\
\text { - } \text { assessment } \\
\text { - } \quad \text { Key stagition of informal assessment } \\
\text { - } \quad \text { Reasons for using oral questions } \\
\text { - Definition and use of different types of } \\
\text { - } \text { feedback } \\
\text { - } \quad \text { Seer assessment and its use } \\
\text { - Use of results to improve learning }\end{array}$ \\
\hline
\end{tabular}

\section{Unpacking summative and formative assessment}

The CAPS documents reviewed list the key concepts required and provides a clear rationale for the effective use of assessment to improve learning and teaching. However, no additional information is provided outlining the specific knowledge and skills required for teachers to enhance both their summative and formative assessment knowledge and skills, or how these should be implemented in the classroom (Kanjee \& Sayed 2013). In order to address this limitation, we developed an integrated framework for summative and formative assessment, drawing on the work of Black and Wiliam (1998); Brookhart (2011); Clarke (2005); Heritage (2007); McMillan (2011); Nitko and Brookhart (2010); Stiggins, Arter, Chappuis and Chappuis (2006); Wiliam and Thompson (2007); and Wiliam (2011). Given the relevance of the CAPS documents (RSA DBE 2011a; 2011b; 2011c; 2011d; 2011e), we sought to incorporate the key concepts and rationale specified for South African teachers in this framework.

\section{Summative assessment framework}

The framework for summative assessment was based on the information for formal assessment activities stipulated in the National protocol for assessment (RSA DBE 2011a), with a focus on the effective use of evidence obtained from any formal 
assessment exercise for use in improving learning and teaching. Formal assessment, according to the foundation phase curriculum and assessment policy statements compromises "a variety of forms of assessment (observation, oral, practical and written) [...] used to give each learner the opportunity to demonstrate what he or she can do" (RSA DBE 2011 :456). This framework thus comprises of the following:

\section{- Clarifying learning objectives, targets and progressions}

Learning objectives and targets specify what learners need to know and be able to do, and are derived from the national curriculum (Stiggins et al 2006), while learning progressions should clearly articulate the sub-goals that constitute progress toward the ultimate goal (Clarke 2005). Specifically, the learning objectives provide information for teachers to determine the purpose of the assessment. Heritage (2007) notes that developing learning progressions toward curriculum objectives is a critical element of the assessment process, as they provide the big picture of what is to be learned and help teachers locate learners' current learning status on the continuum along which they are expected to progress.

\section{- Developing valid assessment instruments}

To develop high quality assessment instruments, McMillan (2011) notes that teachers must ask five key questions:

i. Do I have clear and appropriate learning targets?;

ii. What method of assessment will match best with the targets?;

iii. Will I have good evidence that the inferences from the assessment will be valid and reliable?;

iv. Will my assessment be fair and unbiased?; and

v. Do students have the opportunity to learn what is being assessed?

In practice, this process requires the following knowledge and skills:

(a) Development of the 'table of specification' - a guide that lists the learning targets and content as well as the number and types of items to be included in the assessment (relevant primarily for standardised tests) (Nitko \& Brookhart 2010);

(b) Selection and/or writing of assessment items, which can either be identified and obtained from a range of sources, including textbooks, teacher guides and/or online resources, or written by teachers themselves;

(c) Compilation of the assessment instrument. For standardised tests, this process comprises the order and presentation of items, the allocation of time, the inclusion of exemplars, the instructions provided to learners, and the allocation and specification of marks. For other types of instruments, for example assignments or projects, this process requires clear specification of 
what is required from learners, as well as provision of relevant rubrics or guidelines for how learner responses will be graded;

(d) Development of the rubric (or marking memorandum). A rubric refers to a coherent set of criteria for evaluating learners' work that includes descriptions of levels of performance quality on the criteria (Brookhart 2013). Rubrics are used to assess learner performance and provide detailed information on the evidence that learners are required to demonstrate, as well as the specific mark allocation. Brookhart (2013) notes that the key advantages of using rubrics is that it can be shared with learners, as it makes explicit the link between assessment and instruction, it can be used for summative purposes and it provides teachers with diagnostic information for giving relevant feedback to learners; and

(e) Administration of the instrument. The administration process refers to the conditions and context under which learners are required to respond to the assessment instrument and includes standardised test conditions as well as individual and group assignments and projects that can be completed during class-time or at home.

\section{- Reviewing, grading, analysis and recording}

The process of reviewing, grading, analysing and recording represents the first step in the effective use of information obtained from summative assessments. Specifically, this stage requires teachers to apply the memorandum or rubric to review and analyse the responses of each learner in order to identify what learners know and can do, as well as to determine their specific strengths and weaknesses. Teachers also need to ensure that the assessment results are appropriately recorded so as to facilitate the process of providing appropriate feedback to address the specific learning needs of all learners. In addition, results recorded over long periods of time should be used for monitoring and tracking the progress of learners.

\section{- Reporting and effective use of results}

In the context of classroom assessment, McMillan (2011) argues that all learner performance should be reported against the learning targets; that the primary purpose of any assessment should be to identify learning gaps among learners; and that teachers should use the results to reflect on their teaching practices. Teachers need to ensure that information obtained regarding specific learner's strengths and weaknesses is used to provide clear feedback that learners can use to address weaknesses or to further enhance their current strengths. Specifically, reasons for any increase or decrease in performance need to be identified and communicated to learners, so as to ensure continuous improvements in learning. The nature and format of feedback provided to learners can vary according to the assessments conducted and may include written or oral feedback, or 
a combination of the two. What is critical to this process, however, is that any feedback provided must lead to improvements in learning (Wiliam 2011).

\section{Formative assessment framework}

Wiliam and Thompson (2007) stipulate the following five conditions for the effective use of formative assessment:

\section{- Clarifying and sharing learning intentions and success criteria with the learners}

Sharing the learning objectives and criteria for success with learners helps to prepare them for what they are to be taught in the classroom. The learning intention tells learners what they should know, understand and be able to do, while success criteria list the evidence required to determine whether the learning intention has been achieved. For this condition to be successfully implemented, Wiliam (2011) notes that teachers must ensure that the learning intentions (LI) and success criteria (SC) are presented in learner-friendly language; that all learners understand the $\mathrm{LI}$ and SC; that the $\mathrm{LI}$ and SC are visible to all learners throughout the duration of the lesson; and that they (teachers) refer to the $\mathrm{LI}$ and SC during and at the end of the lesson.

- Managing effective classroom discussions and activities to elicit evidence of learning

This condition relates to how the teacher manages discussions and activities in the classroom to obtain evidence of learning. A range of tasks and activities are utilised to elicit information about learning; for example, using a 'no hands up' policy, so that the teacher is able to call upon all learners to answer questions; allowing a few seconds of 'wait time', so that learners have time to think about their response before answering a question; or giving learners opportunities to discuss and share ideas about questions or tasks with each other to clarify their understanding. Wiliam (2011) notes that a balance should be achieved between open/closed questions and higher order/lower order questions, and that the nature of teachers' questions should provide the basis for later feedback to learners.

\section{- Providing feedback that moves learners forward}

During a lesson, the teacher's feedback, whether written or oral, is crucial for directing the learners' learning. Black and Wiliam (1998:563) define feedback as information that is "useful in closing the gap between actual and desired levels of performance". Thus, feedback can only be regarded as being formative if it leads to an improvement in learning. Once a teacher becomes aware of a gap in learners' performance, the next step should be to provide them with information that will enable them to close the gap, and thus to achieve the desired level of performance. This can be done in writing or verbally, during classroom 
discussions. Brookhart (2008) notes that four factors need to be taken into account to ensure that feedback is effective, namely timing, amount, mode and audience. In addition, the type of feedback that teachers provide (that is, descriptive or evaluate) also impacts on how and what learners learn (ibid).

\section{- Activating learners as learning resources for each other (peer assessment)}

Peer assessment includes evidence of collaborative learning, reciprocal teaching and peer assessment. Black and Wiliam (2004) note that peer assessment encourages learners to act as learning resources for one another and to encourage each other to evaluate their work and that of their counterparts as a way of focusing on their learning. However, Wiliam (2011) argues that teachers must develop specific skills in their learners for peer assessment to be successfully used in the classroom.

\section{- Activating learners as owners of their own learning (self-assessment)}

Self-assessment aims to encourage learners to take ownership of the learning process, as it is through self-assessment that they may begin to accept responsibility for progress towards their own learning goals and outcomes. In order for selfassessment to be useful, learners should be trained by teachers in how to effectively use assessment information to understand the objectives of their learning and how to plan for next steps in improving their learning (Wiliam 2011).

\section{Method}

\section{Data and sample}

Data for this paper was obtained from a larger professional development project conducted by Tshwane University of Technology that focussed on enhancing teachers' classroom assessment practices in order to improve learning and teaching in three primary and two high schools (Kanjee 2013). As part of this project, all teachers in the participating schools completed a reflection exercise to determine their current levels of assessment knowledge, while a sample of teachers was randomly selected for classroom observations, document reviews and interviews to determine their assessment practices. Data from the reflection exercise were obtained from seven teachers in each school, and observation data from one teacher, randomly selected from Grades 1 to 3. Grade $\mathrm{R}$ teachers were excluded, given the focus on informal assessments only in this grade. All teachers in the sample were female, and all three schools, comprising a quintile 2, 3 and 5 school, respectively, were located in an urban area in Gauteng.

\section{Instrument design}

The reflection exercise comprised both open- and closed-ended items regarding key concepts and the rationale pertaining to summative and formative assessment 
stipulated as in the assessment and curriculum policy documents (RSA DBE 2011a; 2011b; 2011c; 2011d; 2011e) and defined in the frameworks presented (See Table 6). Information was also obtained on teachers' use and views of the assessment and curriculum policy documents. The classroom observations and teacher interviews were conducted using semi-structured schedules that focussed on relevant practices outlined in the assessment frameworks; for example, introducing learning intentions or evidence of relevant feedback. In addition, relevant documents, including lesson plans and learner workbooks, were also reviewed.

\section{Scoring and analysis}

Teacher responses were scored on a 50-point scale, with 30 points allocated to knowledge of formative assessment and 20 for summative assessment. Data were analysed based on the percentage of total score obtained, which is indicative of the assessment literacy of the teacher, and sub-scores indicating the teacher's understanding of summative and formative assessment were also calculated. In order to provide a basis for interpretation, scores were categorised into four performance levels - 'Below basic', 'Basic', 'Proficient' and 'Advanced' - indicating different levels of knowledge and understanding (see Table 7).

First, the 'Proficient level' was developed by identifying the minimum levels of knowledge and understanding of the key concepts and procedures identified (See table 6), that teachers would require to effectively use information from both summative and formative assessments in order to support learner improvement. The total scores allocated to each of the different items assessing each concept were added to derive a composite score and converted into a percentage, which in this case was $75 \%$. Thus, a score of $75 \%$ was the minimum score required by teachers to be considered 'Proficient', which is indicative of the teacher demonstrating sufficient understanding regarding the use of both formative and summative assessment information to identify and address learner's specific learning needs. For the 'Advanced level', items indicating knowledge and understanding of using assessment information to improve teaching practices were added to the items for the 'Proficient level'. A minimum score of $90 \%$ was derived for this level. Similarly, items indicating partial understanding were categorised as 'Basic' (minimum score derived $=35 \%$ ), while all other scores were categorised as 'Below basic'.

Table 7: Assessment literacy: Performance levels, score categories and definitions

\begin{tabular}{|l|l|l|l|}
\hline $\begin{array}{c}\text { Performance } \\
\text { level }\end{array}$ & $\begin{array}{c}\text { Score range } \\
(\%)\end{array}$ & \multicolumn{1}{|c|}{$\begin{array}{c}\text { Level definition of } \\
\text { assessment literacy }\end{array}$} & \multicolumn{1}{|c|}{ Implications for practice } \\
\hline Below basic & $0-34$ & $\begin{array}{l}\text { Teacher demonstrates } \\
\text { very limited } \\
\text { understanding }\end{array}$ & $\begin{array}{l}\text { Teacher is unable or unlikely to use } \\
\text { assessment information effectively }\end{array}$ \\
\hline
\end{tabular}




\begin{tabular}{|l|l|l|l|}
\hline $\begin{array}{c}\text { Performance } \\
\text { level }\end{array}$ & $\begin{array}{c}\text { Score range } \\
(\%)\end{array}$ & \multicolumn{1}{|c|}{$\begin{array}{c}\text { Level definition of } \\
\text { assessment literacy }\end{array}$} & \multicolumn{1}{|c|}{ Implications for practice } \\
\hline Basic & $35-74$ & $\begin{array}{l}\text { Teacher demonstrates } \\
\text { partial understanding }\end{array}$ & $\begin{array}{l}\text { Teacher is able to use some } \\
\text { assessment information to identify } \\
\text { learning needs, but is unable or } \\
\text { unlikely to address these needs }\end{array}$ \\
\hline Proficient & $75-89$ & $\begin{array}{l}\text { Teacher demonstrates } \\
\text { sufficient understanding }\end{array}$ & $\begin{array}{l}\text { Teacher is able to use both } \\
\text { formative and summative } \\
\text { assessment information to identify } \\
\text { and address learners' specific } \\
\text { learning needs }\end{array}$ \\
\hline Advanced & $90-100$ & $\begin{array}{l}\text { Teacher demonstrates } \\
\text { comprehensive } \\
\text { understanding }\end{array}$ & $\begin{array}{l}\text { Teacher is able to use formative } \\
\text { and summative assessment to } \\
\text { address learners' specific learning } \\
\text { needs and to improve their own } \\
\text { teaching practice }\end{array}$ \\
\hline
\end{tabular}

Table 7 also lists implications for practice, based on the assumption that teachers demonstrating higher levels of knowledge and understanding are more likely to effectively use assessment information in the classroom and thereby support learners to improve learning. However, it is recognised that knowledge and understanding do not automatically translate into implementation or use in practice. In practice, all teachers categorised below the 'Proficient level' demonstrate low levels of assessment literacy, and are most probably unable or unlikely to use assessment information to support learning and teaching in their classrooms. Given the different demands on teachers regarding the implementation and use of formative and summative assessment in the classroom, data about teacher knowledge and understanding of formative and summative assessment are also presented separately(Table 8).

Analysis was also conducted regarding teacher use of policy documents, while the data were also disaggregated in order to compare schools by their quintile category.

Table 8: Summative and formative assessment: Performance levels, score categories and definitions

\begin{tabular}{|l|l|c|l|l|}
\hline \multirow{2}{*}{$\begin{array}{c}\text { Performance } \\
\text { level }\end{array}$} & \multicolumn{2}{|c|}{ Formative Assessment (FA) } & \multicolumn{2}{c|}{ Summative Assessment (SA) } \\
\cline { 2 - 5 } \% Score & $\begin{array}{c}\text { Implication for } \\
\text { practice }\end{array}$ & \% Score & Implication for practice \\
\hline Below basic & $0-34$ & $\begin{array}{l}\text { Teacher is unable to } \\
\text { apply FA strategies in } \\
\text { the class or use FA to } \\
\text { identify learning gaps }\end{array}$ & $0-19$ & $\begin{array}{l}\text { Teacher is unable to } \\
\text { use SA to identify } \\
\text { learning gaps }\end{array}$ \\
\hline
\end{tabular}




\begin{tabular}{|l|l|l|l|l|}
\hline \multirow{2}{*}{$\begin{array}{c}\text { Performance } \\
\text { level }\end{array}$} & \multicolumn{2}{|c|}{ Formative Assessment (FA) } & \multicolumn{2}{c|}{ Summative Assessment (SA) } \\
\cline { 2 - 5 } Basic & $35-64$ & $\begin{array}{c}\text { Implication for } \\
\text { practice }\end{array}$ & \% Score & Implication for practice \\
\hline Proficient & $\begin{array}{l}\text { Teacher is able to apply } \\
\text { some FA strategies } \\
\text { and to identify gaps in } \\
\text { learning, but unable } \\
\text { or unlikely to address } \\
\text { these gaps }\end{array}$ & $20-69$ & $\begin{array}{l}\text { Teacher is able to use } \\
\text { SA to identify gaps in } \\
\text { learning, but unable } \\
\text { to use information to } \\
\text { address gaps }\end{array}$ \\
\hline Advanced & $65-79$ & $\begin{array}{l}\text { Teacher is able to } \\
\text { effectively apply all FA } \\
\text { strategies and use FA } \\
\text { to identify and address } \\
\text { learning gaps }\end{array}$ & $70-89$ & $\begin{array}{l}\text { Teacher is able to } \\
\text { effectively use SA to } \\
\text { identify and address } \\
\text { learning gaps }\end{array}$ \\
\hline $80-100$ & $\begin{array}{l}\text { Teacher is able to } \\
\text { effectively apply and } \\
\text { use FA to improve } \\
\text { learning and teaching } \\
\text { practices }\end{array}$ & $90-100$ & $\begin{array}{l}\text { Teacher is able to } \\
\text { effectively use SA to } \\
\text { address learning gaps } \\
\text { and review and improve } \\
\text { teaching practices }\end{array}$ \\
\hline
\end{tabular}

\section{Results and discussion}

Figure 1 provides an overview of teachers' assessment literacy and their level of understanding of summative and formative assessment. For approximately half of the teachers, assessment literacy is at the 'Basic' level, with the other half at the 'Below basic' level, indicating a very limited understanding of assessment. Similarly low levels of assessment literacy were also reported by Yamtim and Wongwanich (2014) in a study of primary school teachers in Thailand. The authors adapted the Classroom Assessment Literacy Inventory, which was based on the Standards for Teacher Competence in Educational Assessment of Students (AFT, NCME \& NEA 1990), to the Thai context, and reported assessment literacy levels using three performance levels, which they defined as 'Poor' (lower than 60\%); 'Fair' (60\%-79\%); and 'Good' ( $80 \%$ and higher). They found that $78.5 \%$ of teachers had scores at the lowest ('Poor') level (ibid:3003). 


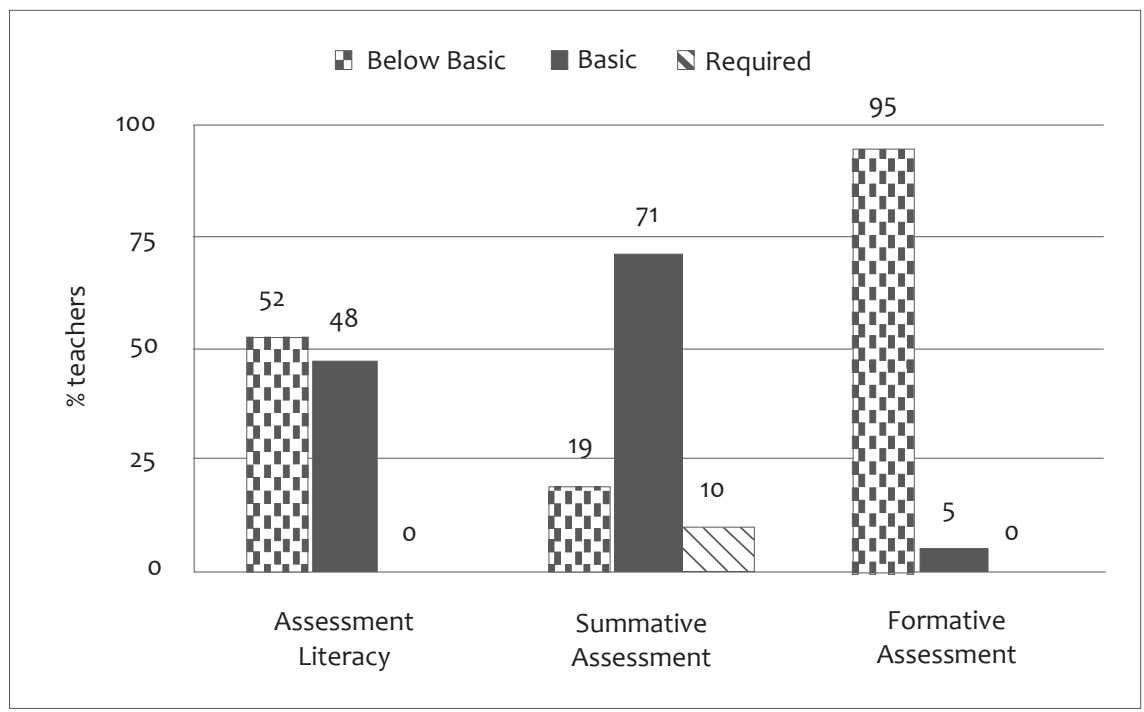

Figure 1: Level of teacher assessment literacy and understanding of summative and formative assessment

Further analysis revealed that approximately two-thirds of teachers in this study demonstrated a 'Basic' understanding of summative assessment and about a fifth demonstrated 'Below basic' understanding, with only 10\% demonstrating a 'Proficient' level of understanding regarding the use summative assessment. With regard to formative assessment, all but one teacher demonstrated 'Below basic' understanding, with one teacher demonstrating 'Basic' understanding. The implications for practice are that most of the teachers demonstrated partial understanding regarding the use of summative assessment to identify learning gaps, and demonstrated limited knowledge in terms of being able to act on this information in order to address these gaps. Only $10 \%$ of teachers (that is, two individuals) fell in the latter category. As for formative assessment, no teacher demonstrated sufficient understanding to enable them to use assessment information in order to address learning gaps.

Analysis of the observation data verified this finding. While all three teachers observed were clear in the introduction of the lesson, none of them engaged in any activities to determine whether learners had understood the lesson purpose; nor did they ensure that the lesson intentions were visible at all times during the lesson. In the foundation phase, these learning intentions could be presented graphically or in simple, learner-friendly language (Clarke 2005). In addition, none of the teachers introduced success criteria. With regard to teacher questioning practices, questions were posed based on the traditional approach of only requesting a response from those learners who had their hands up (Wiliam 2011). None of the teachers used the 'no hands up' approach; nor did they allow for any 'wait time' before learners could provide a response. A review of learner workbooks (three from each teacher - one 
each from a high-, average and low-performing learner) found no evidence of effective feedback being provided to learners. Instead, feedback from all teachers comprised of ticks, crosses and occasional comments such as 'good work', 'keep it up', and 'good'.

It is important to clarify that these findings do not imply that teachers are not teaching or that learners are not learning. Rather, the findings indicate that teachers are unable to determine whether learners are learning what they (the teachers) are teaching, and thus unable to provide support to those learners who require additional assistance to attain the curriculum objectives. In his research on teacher impact on student learning, Wiliam (2011) notes that the concept of 'effective quality' implies that teachers are not only able to identify specific learning needs in their students, but also to take appropriate steps to address these needs. Thus, effective assessment practice has a significant impact on learning: "[...] students who are fortunate enough to be taught by the most effective teacher will learn in six months what those taught by the average teacher will take a year to learn" (ibid:20). Moreover, at-risk students stand to benefit the most, as reported by Hamre and Pianta (2005). These authors studied teachers' use of assessment to identify and address the specific learning needs of atrisk students, and found that students who were provided with strong instructional and emotional support demonstrated similar achievement scores as those of their low-risk peers, while at-risk students placed in less supportive classrooms had lower achievement scores.

The finding that teachers demonstrated low levels of assessment literacy is hardly surprising, as is the finding that teachers were more knowledgeable about summative assessment than formative assessment. A number of studies in South Africa have reported that teachers' assessment practices are seriously wanting in terms of supporting the learning needs of their learners (Hariparsad 2004; Kanjee \& Croft 2012; Pryor \& Lubisi 2002; Ramsuran 2006; Sokopo 2004). Hariparsad's (2004) study of two Grade 8 science teachers showed that the teachers invariably favoured traditional examinations and tests in their practice, as they had only a surface understanding of the new assessment policies and were unable to reconcile these with their own deeprooted assessment beliefs and capacities. Similarly, Sokopo (2004) found that teachers lacked understanding of the policies and struggled with their implementation, as they essentially believed that classroom assessment was merely for the accumulation of marks. Regarding teachers' knowledge and use of formative assessment in primary schools, Kanjee and Croft (2012) reported that they had found no evidence that teachers understood the concept of formative assessment, nor any evidence of its use in the classroom.

Teachers were also asked to report on their use of relevant assessment policy documents (that is, the CAPS (RSA DBE 2011a; 2011b; 2011c; 2011d; 2011e) and Revised National Curriculum Statement (RSA DoE 2002)). Two-thirds of the teachers reported that they use the policy 'often' or 'sometimes', while a third indicated 'rarely'. As indicated in Figure 2, assessment literacy ( $\mathrm{AL}$ ), summative assessment (SA), and formative assessment (FA) mean scores were higher for those who responded 'often' or 'sometimes'. However, no significant differences were found between the means scores of teachers who reported 
that they used the policy 'often' or 'sometimes', and those who reported that they 'rarely' used it, a result that may be due to the small sample sizes. Yet this finding does allude to the need for additional information regarding the value and use of the assessment and curriculum policies for enhancing teacher understanding and classroom practice. Similar findings have been reported by a number of other studies. In their study on teachers' conceptions and practice of classroom assessment, Vandeyar and Killen (2007) reported that the lack of clear guidelines about how assessment should be applied in the classroom in order to improve learning and teaching was a key challenge for teachers. Similarly, the Ministerial Task Team for the Review of the Implementation of the National Curriculum Statements found that the failure to update the 1998 assessment policy in the 2002 Revised National Curriculum Statement

resulted in numerous attempts to determine and clarify an assessment policy. This has resulted in assessment policy that is misunderstood and inconsistent throughout the system and that is extremely onerous for teachers in terms of its requirements.

(RSA DBE 2009:31)

In their review of the assessment policy process in the post-apartheid era, Kanjee and Sayed (2013) also note that the most recent assessment policy (RSA DBE 2011a) fails to provide adequate information and guidelines for teachers regarding the effective use of assessment in the classroom. This limitation may explain the limited knowledge and understanding of teachers (as indicated by the findings of the present study) regarding the effective use of assessment to improve learning and teaching.

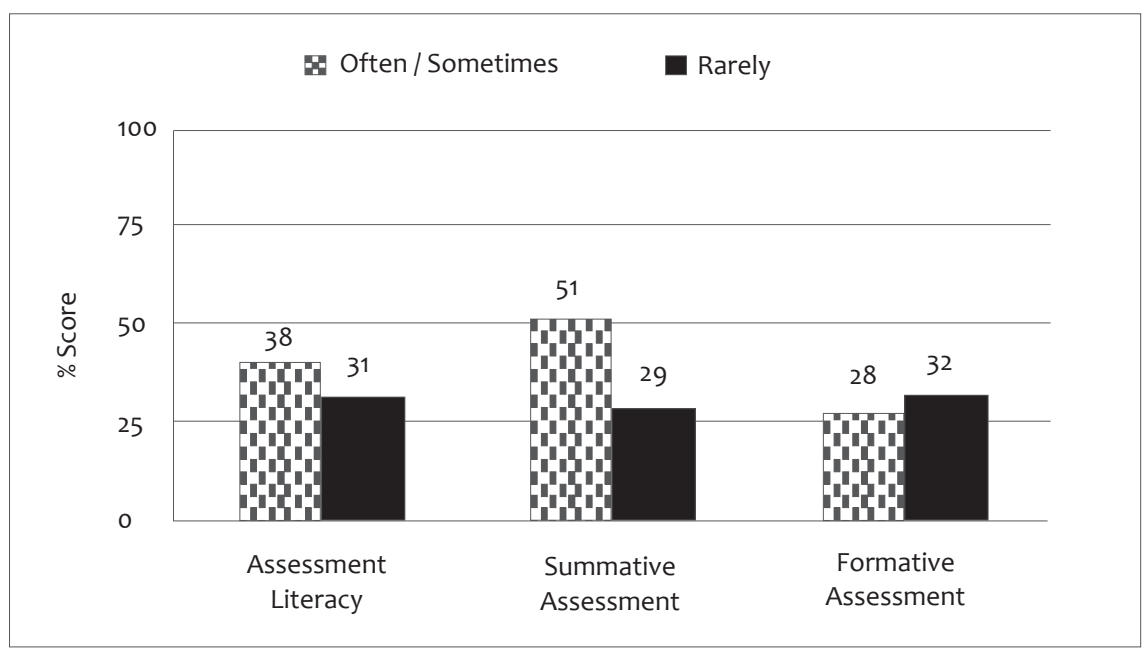

Figure 2: Mean percentage scores for assessment literacy, summative assessment and formative assessment by frequency of policy usage 


\section{Comparisons by quintile category}

Analysis was also conducted to compare teacher assessment literacy levels by school quintile, where quintile 2 (Q2) represents poorly-resourced and generally lowperforming schools with mainly poorly qualified teachers and learners from low socioeconomic backgrounds, and quintile 5 (Q5) represents well-resourced and generally higher or better performing schools with better qualified teachers and learners from middle to high socio-economic backgrounds. It was expected that teachers from the Q5 school would demonstrate significantly higher levels of understanding and knowledge, given their higher levels of training and qualification. Table 9 provides the mean scores for assessment literacy and summative and formative assessment by school quintile, while Figure 3 provides assessment literacy performance levels by school quintile. While these results show differences in means scores for AL, SA and FA across the school quintiles, the results of an ANOVA (for AL $F(1,18)=.99, p=.332$; for SA $F(1,18)=.89, p=.357$; for $F A F(1,18)=.41, p=.529)$ indicated that these differences were not statistically significant. Similarly, a review of Figure 3 indicates minimal differences in the number of teachers from each of the three school quintiles located at the "Below basic' and 'Basic' levels in terms of their understanding of AL.

Table 9: Mean scores (\%) for AL, SA and FA by school quintile

\begin{tabular}{|c|c|c|c|c|c|}
\hline & $\begin{array}{l}\text { Quintile } \\
\text { category }\end{array}$ & $\mathbf{N}$ & Mean & SD & SE \\
\hline \multirow{4}{*}{$\begin{array}{l}\text { Assessment } \\
\text { literacy }(A L)\end{array}$} & Q2 & 7 & 26.86 & 12.48 & 4.72 \\
\hline & Q3 & 7 & 36.29 & 6.37 & 2.41 \\
\hline & Q5 & 7 & 34.00 & 12.28 & 4.64 \\
\hline & Total & 21 & 32.38 & 11.00 & 2.40 \\
\hline \multirow{4}{*}{$\begin{array}{l}\text { Summative } \\
\text { assessment } \\
\text { (SA) }\end{array}$} & Q2 & 7 & 32.86 & 23.60 & 8.92 \\
\hline & Q3 & 7 & 50.00 & 15.28 & 5.77 \\
\hline & Q5 & 7 & 46.43 & 25.45 & 9.62 \\
\hline & Total & 21 & 43.10 & 22.11 & 4.82 \\
\hline \multirow{4}{*}{$\begin{array}{l}\text { Formative } \\
\text { assessment } \\
\text { (FA) }\end{array}$} & Q2 & 7 & 21.86 & 9.49 & 3.59 \\
\hline & Q3 & 7 & 26.00 & 4.12 & 1.56 \\
\hline & Q5 & 7 & 25.00 & 7.42 & 2.80 \\
\hline & Total & 21 & 24.29 & 7.21 & 1.57 \\
\hline
\end{tabular}




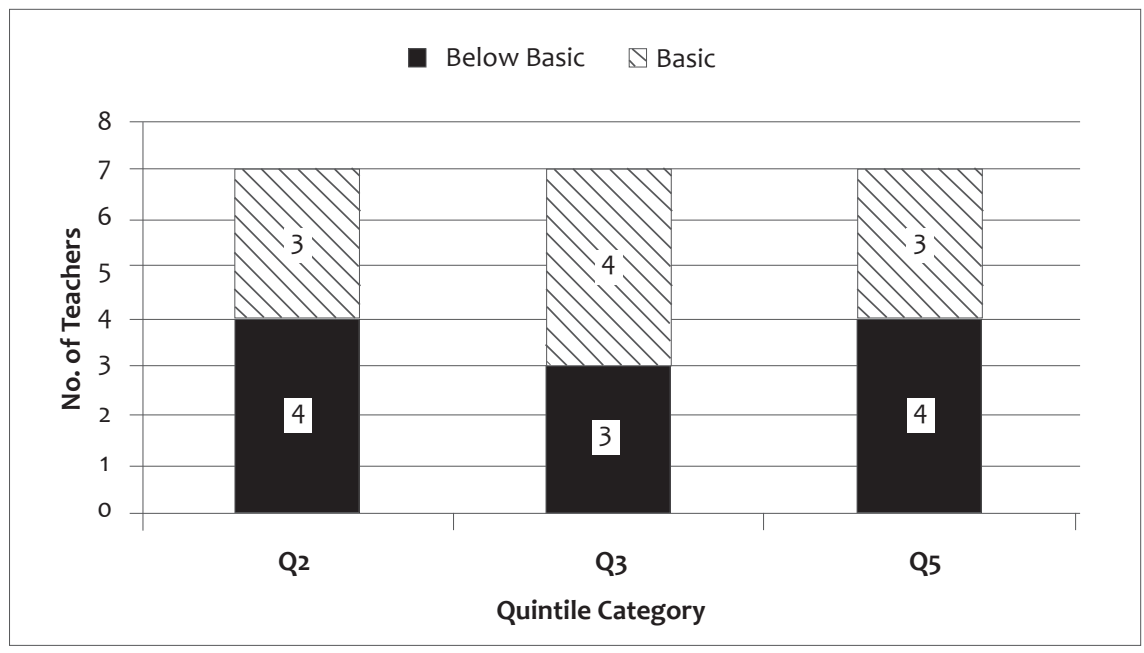

Figure 3: Assessment literacy performance levels by school quintile

In summary, these results indicate little or no difference between teachers from schools across the quintile categories in terms of their levels of assessment literacy in general, and summative and formative assessment in particular. It must be acknowledged that these findings are based on a limited sample of twenty-one teachers from three schools, and cannot be generalised to the larger population of teachers and schools. In addition, no information was obtained on the different practices or cultures at the specific schools, which may impact on teachers' assessment practices. However, similar findings were reported in other studies as well. In their study comparing formative assessment practices in one well-resourced urban school and four under-resourced rural schools, Kuze and Shumba (2011:169) found that, "although teachers seem to be willing to implement FA in the classroom, they lack knowledge of how FA should be implemented". Similarly, in their study on assessment practices in eight primary schools, Kanjee and Croft (2012:13) reported "equally poor" assessment practices among teachers across schools in different quintile categories.

\section{Conclusion}

The purpose of this study was to explore foundation phase teachers' assessment literacy and their understanding and use of formative and summative assessment in the classroom. The current curriculum and assessment policies served as the basis for conceptualizing assessment literacy relevant to teachers in South African schools. The findings indicate that teachers in this study demonstrated very low levels of assessment literacy, with approximately half of the teachers performing at the 'Below basic' level and half at the 'Basic' level. Teacher understanding of summative assessment was found to be noticeably higher, with two-thirds demonstrating a 'Basic' understanding, and 10\% demonstrating a 'Proficient' level of understanding. 
Vey concerning, however, is that all but one teacher demonstrated 'Below basic' understanding of formative assessment. Observations of teacher classroom practices also supported these findings. The findings resonate with the argument presented by Kanjee and Sayed (2013), who noted that

[...] while revisions of the assessment policy continue to advocate for the formative use of assessment information, they promote the implementation of the summative use of assessment, relegating the former to the category of 'symbolic policy'. This is manifested in the form of CASS, with the privileging of formal testing over informal assessment, and thereby promoting a discourse of reporting and recording as opposed to a discourse of using assessment for improving learning and teaching.

(Kanjee \& Sayed 2013:465)

The implications for practice are dire, as the results indicate that teachers are unable to effectively use assessment to support their learners and address their learning needs, and highly unlikely to be able to use assessment information to improve their own teaching practices. A comparison of teachers according to school quintile category indicates equally low levels of understanding across all three schools in the study. In addition, no differences in levels of assessment literacy were found between teachers reporting that they 'often' or 'sometimes' use the assessment policy and those reporting that they 'rarely' used it.

It must be acknowledged that the results of this study are based on a limited sample of teachers and schools (twenty-one teachers from three schools), and thus cannot be generalised to the larger population. However, the results corroborate findings reported in a number of other studies, albeit also based on small samples, regarding teacher assessment knowledge and practices in South African schools. More importantly, it is our intention that the findings will contribute to the ongoing debate about improving learning and teaching in South African schools, and in particular, to enhancing professional development programmes for teachers. In this regard, the formative and summative assessment frameworks developed for this study provide a good starting point regarding relevant content for these programmes. However, further research is required regarding effective models for implementation of both in-service and pre-service professional development programmes. Another area for debate and further research pertains to the conceptualisation of assessment literacy and its relevance to the South African context.

Additional research is also required to determine the extent to which available professional development programmes support teachers in enhancing their assessment literacy, and whether these skills are effectively applied to address the learning needs of all learners across schools in the different quintile categories. In addition, the study also points to the need for a thorough review of the underlying notions and practices advocated in the assessment and curriculum policies, as well as the specific interpretations regarding summative and formative assessment, and how this impacts on the functioning of schools and the classroom practices of teachers. Finally, the findings pertaining to the 'equally poor' levels of understanding and knowledge demonstrated by teachers across quintile categories call for additional research on the 
specific contributions that foundation phase teachers make in addressing the learning needs of learners in better resourced and generally higher performing schools compared to learners in poorly resourced and generally low-performing schools.

\section{References}

AFT (American Federation of Teachers), NCME (National Council on Measurement in Education) \& NEA (National Education Association). 1990. Standards for Teacher Competence in Educational Assessment of Students. Washington, DC: American Federation of Teachers.

Black, P. \& Wiliam, D. 1998. Inside the black box: Raising standards through classroom assessment. Phi Delta Kapan, 80:139-148.

Black, P. \& Wiliam, D. 2004. The formative purpose: Assessment must first promote learning. Yearbook of the National Society for the Study of Education, 103(2):20-50.

Brookhart, S.M. 2008. How to give effective feedback. ASCD (Association for Supervision and Curriculum Development).

Brookhart, S.M. 2011. Educational assessment knowledge and skills for teachers. Educational Measurement: Issues and Practice, 30(1):3-12.

Brookhart, S.M. 2013. How to create and use rubrics for formative assessment and grading. ASCD (Association for Supervision and Curriculum Development).

Brown, G.T.L. 2004. Teachers' conceptions of assessment: Implications for policy and professional development. Assessment in Education: Principles, Policy \& Practice, 11(3):301-18.

Clarke, S. 2005. Formative assessment in action: Weaving the elements together. London: Hodder Murray.

DeLuca, C., Chavez, T., Bellara, A. \& Cao, C. 2013. Pedagogies for Preservice Assessment Education: Supporting Teacher Candidates' Assessment Literacy Development. The Teacher Educator, 48(2):128-142.

Gotch, C.M. \& French, B.F. 2014. A systematic review of assessment literacy measures. Educational Measurement: Issues and Practice, 33(2):14-18.

Hamre, B.K. \& Pianta, R.C. 2005. Can instructional and emotional support in the first grade classroom make a difference for children at risk of school failure? Child development, 76(5):949-967.

Hariparsad, S.D. 2004. In search of deep change: A study of the implementation of assessment policy in South African schools. Unpublished PhD Thesis. Pretoria: University of Pretoria.

Hendy, L. \& Whitebread, D. 2000. Interpretations of Independent Learning in the Early Years. International Journal of Early Years Education, 8(3):243-252.

Henning, E. 2013. Teachers' understanding of mathematical cognition in childhood: Towards a shift in pedagogical content knowledge? Perspectives in Education, 31(3):139-154. 
Heritage, M. 2007. Formative assessment: What do teachers need to know and do? Phi Delta Kappan, 89(2):140-145.

Hill, M.F., Smith, L.F., Cowie, B., Gilmore, A. \& Gunn, A. 2013. Preparing initial teacher and early childhood teacher education students to use assessment. Final summary report. Wellington, NZ: Teaching and Learning Research Initiative.

Kanjee, A. \& Croft, C. 2012. Enhancing the use of assessment for learning: Addressing challenges facing South African teachers. Paper presented at the annual American Educational Research Conference, Vancouver, Canada, 13-17 April 2012.

Kanjee, A. \& Sayed, Y. 2013. Assessment policy in post-apartheid South Africa: Challenges for improving education quality and learning. Assessment in Education: Principles, Policy \& Practice, 20(4):442-469.

Kanjee, A. 2009. Enhancing teacher assessment practices in South African schools: Evaluation of the assessment resource banks. Education and Change, 13(1):67-83.

Kanjee, A. 2013. Assessment for learning district capacity development programme. Proposal submitted to the National Research Foundation (NRF). Pretoria: School of Education, Tshwane University of Technology.

Kuze, M.W. \& Shumba, A. 2011. An investigation into formative assessment practices of teachers in selected schools in Fort Beaufort in South Africa. Journal of Social Science, 29(2):159-170.

McMillan, J.H. 2011. Classroom Assessment. Principles and Practices for Effective Instruction. Boston: Allyn \& Bacon.

Niemeyer, J. \& Scott-Little, C. 2001. Assessing kindergarten children: A compendium of assessment instruments. SERVE Center: University of North Carolina at Greensboro.

Nitko, A. J. 1995. Curriculum-based continuous assessment: A framework for concepts, procedures and policy. Assessment in Education: Principles, Policy \& Practice, 2(3):321-337.

Nitko, A.J. \& Brookhart, S.M. 2010. Educational Assessment of Students. $6^{\text {th }}$ Edition. Boston, MA: Pearson Education.

Pahad, M. 1999. Outcomes-based assessment: The need for a common vision of what counts and how to count it. In: J.D. Jansen \& P. Christie (Eds). Changing curriculum: Studies in outcomes-based education in South Africa. Cape Town: Juta. 247-275.

Popham, W.J. 2009. Assessment literacy for teachers: Faddish or fundamental? Theory into Practice, 48(1):4-11.

Pryor, J. \& Lubisi, C. 2002. Reconceptualising educational assessment in South Africa: testing time for teachers. International Journal of Educational Development, 22 (1):673-686.

Pyle, A. \& Deluca, C. 2013. Assessment in the kindergarten classroom: An empirical study of teachers' assessment approaches. Early Childhood Education Journal, 41(5):373-380.

Quilter, S. \& Gallini, J.K. 2000. In-service teachers' assessment literacy and attitudes toward assessment. The Teacher Educator, 36(2):115-131. 
Ramsuran, A. 2006. How are teachers' understandings and practices positioned in discourses of assessment? Proceedings of the 4th Sub-Regional Conference on Assessment in Education. Johannesburg, 26-30 June 2006. 337-346.

Rao, N. \& Sun, J. 2010. Early Childhood Care and Education in the Asia-Pacific Region: Moving towards Goal 1. Hong Kong: Comparative Education Research Centre, University of Hong Kong/UNESCO.

Richardson, V. 2003. Preservice teachers beliefs. In: J. Raths \& A.C. McAninch (Eds). Teacher beliefs and classroom performance: The impact of teacher education. Greenwich, CT: Information Age Publishing. 1-22.

RSA DBE (Republic of South Africa. Department of Basic Education). 2009. Report of the Task Team for the review of the implementation of the National Curriculum Statements. Pretoria: Department of Basic Education.

RSA DBE (Republic of South Africa. Department of Basic Education). 2011a. National protocol for assessment: Grades R-12. Pretoria: Department of Basic Education.

RSA DBE (Republic of South Africa. Department of Basic Education). 2011b. National curriculum statement (NCS): Curriculum and policy statement: First Additional Language foundation phase Grades 1-3. Pretoria: Department of Basic Education.

RSA DBE (Republic of South Africa. Department of Basic Education). 2011c. National curriculum statement (NCS): Curriculum and policy statement: Home Language foundation phase Grades 1-3. Pretoria: Department of Basic Education.

RSA DBE (Republic of South Africa. Department of Basic Education). 2011d. National curriculum statement (NCS): Curriculum and policy statement: Life Skills foundation phase Grades 1-3. Pretoria: Department of Basic Education.

RSA DBE (Republic of South Africa. Department of Basic Education). 2011e. National curriculum statement (NCS): Curriculum and policy statement: Mathematics foundation phase Grades 1-3. Pretoria: Department of Basic Education.

RSA DBE (Republic of South Africa. Department of Basic Education). 2012. Annual National Assessments 2011 Report. Pretoria: Department of Education.

RSA DoE (Republic of South Africa. Department of Education). 1997a. National Curriculum Statement: Assessment guidelines for Mathematics (Intermediate and Senior Phases). Pretoria: Department of Education.

RSA DoE (Republic of South Africa. Department of Education). 1997b. National Curriculum Statement: Assessment guidelines for Language (Intermediate and Senior Phases). Pretoria: Department of Education.

RSA DoE (Republic of South Africa. Department of Education). 1998. Assessment policy in the general education and training band: Grades R to 9 and ABET. Government Gazette, no 19640. Pretoria: Government Printers.

RSA DoE (Republic of South Africa. Department of Education). 2000. A South African Curriculum for the twenty-first century: Report of the Review Committee on Curriculum 2005. Pretoria: Government Printers. 
RSA DoE (Republic of South Africa. Department of Education). 2002. Revised National Curriculum Statement Grades R-9 (Schools) Overview. Government Gazette, no 23406. Pretoria: Government Printers.

RSA DoE (Republic of South Africa. Department of Education). 2007. National Policy on Assessment and Qualifications for Schools in the General Education and Training Band. Pretoria: Department of Education.

Sayed, Y., Kanjee, A. \& Rao, N. 2014. Assessment and Learning: Problems and Prospects. In: D. Wagner (Ed). Learning and education in developing countries: Research and policy for the post-2015 UN Development Goals. New York: Palgrave Macmillan. 91-109.

Sethusha, M.J. 2012. Primary school teachers' conceptions of classroom assessment: A qualitative study. International Journal of Cross-Disciplinary Subjects in Education, 3(2):699-706.

Shepard, L.A., Kagan, S.L. \& Wurtz, E. 1998. Goal 1 Early Childhood Assessments Resource Group Recommendations. Public Policy Report. Young Children, 53(3):52-54.

Sokopo, Z.N. 2004. The interactional effects of different assessment policies on the assessment practices of Grade 9 teachers. PhD Thesis. Pretoria: University of Pretoria.

Stiggins, R.J. 1995. Assessment literacy for the $21^{\text {st }}$ century. Phi Delta Kappan, 77:238-238.

Stiggins, R.J. 1999. Are you assessment literate? High School Magazine, 6(5):20-23.

Stiggins, R.J., Arter, J.A., Chappuis, J. \& Chappuis, S. 2006. Classroom assessment for student learning: Doing it right - using it well. $2^{\text {nd }}$ Edition. Pearson Assessment Training Institute, Inc Series. Boston, MA: Pearson.

Thompson, A.G. 1992. Teachers' beliefs and conceptions: A synthesis of the research. In: D.A. Grouws (Ed). Handbook of research on mathematics teaching and learning. New York: MacMillan. 127-146.

Van Laren, L.V. \& James, A. 2008. Selected teachers' understanding of assessment four years after the implementation of the New Assessment Policy. Africa Education Review, 5(2):288-303.

Vandeyar, S. \& Killen, R. 2007. Educators' conceptions of classroom assessment in postapartheid South Africa. South African Journal of Education, 27(1):101-115.

Wiliam, D. \& Thompson, M. 2007. Integrating assessment with instruction: what will it take to make it work? In: C.A. Dwyer (Ed). The future of assessment: shaping teaching and learning. Mahwah, NJ: Lawrence Erlbaum Associates. 53-82.

Wiliam, D. 2011. Embedded formative assessment. Bloomington, IN: Solution Tree Press.

Yamtim, V. \& Wongwanich, S. 2014. A study of classroom assessment literacy of primary school teachers. Procedia - Social and Behavioural Sciences, 116:2998-3004. 